\title{
POPULATIONS OF ARTEMIA CRUSTACEANS OF KARABASSKY FLOODS OF PRIBALKHASHYE ${ }^{1}$
}

\author{
Zh. O. Mazhibayeva, T. T. Barakbayev, G. M. Shalgimbayeva, \\ K. B. Isbekov, S. Zh. Assylbekova, V. V. Fefelov
}

Fisheries Research and Production Center, LLP, Almaty, Republic of Kazakhstan

\begin{abstract}
The article presents the analysis of biological parameters of parthenogenetics of Artemia crustaceans of the hypergaline reservoirs of Kazakhstan. In the lakes under study there are shown the changes of the total crustacean biomass decreasing from high-productive to lowproductive. Most of the reservoirs with Artemia in Kazakhstan are characterized by the presence of Artemia parthenogenetic populations with the absence or extremely small presence of males. The aggregation of males in significant numbers may indicate the tension of the ecological situation in the reservoirs and the desire of the population to increase the survival and stability of the offspring. It has been stated that all age periods of crustacean maturation are found in the reservoirs. At the same time, the basis of Artemia populations in all studied lakes are the youngest stages - nauplius, which form $53-86 \%$ of the total number of Artemias. In lakes Artemia crustaceans are presented by bisexual parthenogenetic race, with all age stages of development during the summer - autumnal period of observations. The hydrochemical mode of hypergaline lakes of Karabassky floods is favorable for activity of Artemia Branchiopoda crustaceans. The size of crustacean biomass populations in Lake Balhash change on seasons ranging from low to very high. Lake No. 1 is highly productive in Artemias in the summer, and lake No. 2 - in the spring. Such difference in temporary aspect is caused by existence of various generations in the populations of the crustaceans on seasons. The data obtained prove the high potential of the studied small reservoirs of the Balkhash region in relation to autumn plankton cysts.
\end{abstract}

Key word: lakes, population, Artemia, crustaceans, cysts, biomass, plankton.

For citation: Mazhibayeva Zh. O., Barakbayev T. T., Shalgimbayeva G. M., Isbekov K. B., Assylbekova S. Zh., Fefelov V. V. Populations of Artemia crustaceans of Karabassky floods of Pribalkhashye. Vestnik of Astrakhan State Technical University. Series: Fishing Industry. 2021;3:47-54. (In Russ.) DOI: 10.24143/2072-9502-2021-3-47-54.

\section{Introduction}

The Artemia gill-footed crustaceans have gained the popularity in many countries. Now the cyst consumption of Artemia around the world makes about 10 thousand tons per year [1,2]. Within the last two decades the need for products of an aquaculture annually increases by $5-10 \%$ that assumes also an increase in demand on Artemia. Now in the world seven species of Artemia crustacean are discovered, and all of them treat valuable food objects for trade species of fish and other hydrobionts [3].

Kazakhstan possesses 10-15\% of world reserves of Artemia, the production limit of Artemia cyst from the Republic reservoirs for 2019 is set of 1492.81 tons (limit/quota). The main part of the specified volume is made by the lakes of the Pavlodar region (1 116.0 tons per year).

At the increase of the mineralization of water, when the reservoirs are drying or freezing, Artemias form the diapausing ranges - cysts who are beyond all bounds in a condition of temporary physiological rest. The ability of cysts to restore activity in favorable conditions defines the broad prospect of using them as starting live forages at all seasons of the year. Artemia is widespread worldwide and inhabits reservoirs of continental and sea origin with a range of salinity from 20 to $340 \mathrm{~g} / \mathrm{l}$. It differs in high and rather stable contents in a protein body - up to $70 \%$ of a protein in solid of a crustacean, the considerable level of irreplaceable amino acids, hormones, carotenoids, vitamins, valuable fatty acids. Besides, having a wide variety of physiological, biochemical, morphological properties in separate populations, in general Artemia possesses the well expressed by adaptive fitness to changes habitat conditions. The development of a bioresource of cyst Artemia in salty reservoirs of Kazakhstan, maybe, one of the

${ }^{1}$ Данное исследование финансируется Комитетом науки Министерства образования и науки Республики Казахстан (Грант № АР09058158 на исследование экспортно-ориентированного биоресурса Artemia franciscana для разработки биологического обоснования их внедрения, для повышения продуктивности засоленных водоемов РК). 
main directions of development of domestic production of starting bioforages of water origin for needs of fish breeding and aquaculture. There are little works on studying the biology and ecology of Branchiopoda crustaceans living on extensive space of Kazakhstan. Scarce reports or incomplete data can be met in works [1, 2, 4, 5]. In reservoirs of Kazakhstan Artemia is identified as Artemia parthenogenetica by molecular and genetic methods [1].

The purpose of works was to carry out the analysis of hydrological, hydrochemical indicators and stocks of Artemia cyst and crustacean in the Karabassky gulfs of Pribalkhashye.

\section{Material and research methods}

In 2021 we have surveyed the state and efficiency of Artemia populations in 5 lakes of Karabassky floods of Pribalkhashya. Determining the water key parameters, collecting and processing hydrobiological material were carried out according to the standard techniques [6-11]. Tests of plankton with Artemia and cysts were selected by the Apstein's network and fixed by $40 \%$ formalin. Statistical processing of biological data is executed by the Microsoft Office and Excell applications. The coordinates were determined with the help of the GPS navigation system - the Garmin navigator (Taiwan). The studied reservoirs have the general name Karabassky floods (the system of the lakes Zhantelikol), in this regard further we used numbering of reservoirs. The coordinates of the studied lakes: the 1 lake - NL 46028'23", EL 76015'08"; 2 - NL 46028'46", EL 76015'20", 3 - NL 46029'39", EL 76017'01"; 4 - NL 46030'08", EL 76029'23" and the 5th lake - NL 46030'46", EL 76022'55".

\section{Results and discussion}

The hypergaline (salt) lakes of the Karabassky floods in the Karatalsky district of the Almaty region. Reservoirs are located at the altitude from 337 to $339 \mathrm{~m}$ above sea level. The area of a water mirror of the lakes, which are a part of the Karabassky floods is 10000 hectares, from them 730.7 hectares were examined. The main characteristics of model lakes of the Karabassky floods are presented in Table 1.

Table 1

Characteristic of lakes of the Karabassky floods

\begin{tabular}{|c|c|c|c|c|c|c|c|c|c|}
\hline $\begin{array}{c}\text { Place of } \\
\text { collecting }\end{array}$ & $\begin{array}{c}\text { Altitude, } \\
\text { m }\end{array}$ & $\begin{array}{l}\text { Area of the } \\
\text { reservoir, ha }\end{array}$ & $\begin{array}{l}\text { Length, } \\
\text { km }\end{array}$ & $\begin{array}{c}\text { Greatest } \\
\text { width, km }\end{array}$ & $\begin{array}{c}\text { Coastline } \\
\text { length, } \\
\text { km }\end{array}$ & $\begin{array}{c}\text { Maximum } \\
\text { depth, } \mathbf{m}\end{array}$ & $\begin{array}{l}\text { Average } \\
\text { depth, } m\end{array}$ & $\begin{array}{l}\text { Water mass } \\
\text { volume, } \mathbf{m}^{3}\end{array}$ & $\begin{array}{c}\text { Volume of } \\
\text { "residential } \\
\text { zone", } \\
\text { million m }{ }^{3}\end{array}$ \\
\hline 1 & 338 & 1.0 & 0.22 & 0.06 & 0.58 & 0.8 & 0.4 & 0.004 & 0.003 \\
\hline 2 & 338 & 0.2 & 0.05 & 0.04 & 0.16 & 0.8 & 0.3 & 0.001 & 0.001 \\
\hline 3 & 337 & 8.6 & 0.44 & 0.32 & 1.61 & 1.0 & 0.4 & 0.034 & 0.029 \\
\hline 4 & 337 & 12.0 & 0.58 & 0.33 & 1.97 & 0.7 & 0.3 & 0.036 & 0.031 \\
\hline 5 & 337 & 128.6 & 2.94 & 1.17 & 11.72 & 1.1 & 0.5 & 0.643 & 0.545 \\
\hline
\end{tabular}

The maximum depth in the reservoirs is from 0.7 to $1.4 \mathrm{~m}$, the average depth makes no more than $0.6 \mathrm{~m}$. Food of the reservoirs is generally carried out due to the spring snowmelt and atmospheric precipitation, As well as due to the water area of lakes. Besides the food of reservoirs, the significant role is played by the waters of Lake Balkhash, which get to lakes through underground soil. The coast of the majority of reservoirs are high, in some cases abrupt, up to $7-10 \mathrm{~m}$ high. The bottom is dense, sandy, rarer clay with impurity of gray silt, the power of silt deposits is about $0.2 \mathrm{~m}$. The water mineralization in salt lakes of the Karabassky floods made from 66.55 to $179.25 \mathrm{~g} / \mathrm{dm}^{3}$ that is the favorable environment for existence of a Branchiopoda crustacean - Artemia and existence a cyst. The ion-salt structure of lakes of the Karabassky gulfs, as of 2021 is presented in Table 2.

Table 2

Ion-salt composition* of the lakes of the Karabassky gulfs, 2021

\begin{tabular}{|c|c|c|c|c|c|c|c|}
\hline $\begin{array}{l}\text { Sequence number } \\
\text { of the reservoir }\end{array}$ & $\underset{\mathrm{mg} / \mathrm{dm}^{3}}{\mathrm{Ca}^{2+}}$ & $\begin{array}{c}\mathrm{Mg}^{2+} \\
\mathrm{mg} / \mathrm{dm}^{3}\end{array}$ & $\begin{array}{l}\mathrm{Na}^{+}+\mathrm{K}^{+}, \\
\mathrm{mg} / \mathrm{dm}^{3}\end{array}$ & $\begin{array}{l}\mathrm{SO}_{4}{ }^{2-} \\
\mathrm{mg} / \mathrm{dm}^{3}\end{array}$ & $\begin{array}{l}\mathrm{HCO}_{3}^{-}, \\
\mathrm{mg} / \mathrm{dm}^{3}\end{array}$ & $\begin{array}{c}\mathrm{Cl}^{-}, \\
\mathrm{mg} / \mathrm{dm}^{3}\end{array}$ & $\begin{array}{l}\text { Mineraliza- } \\
\text { tion, } \mathbf{m g} / \mathbf{d m}^{3}\end{array}$ \\
\hline 1 & 98.0 & 462.0 & 10550.0 & 1432.0 & 5185.0 & 48825.0 & 66552.0 \\
\hline 2 & 870.0 & 11142.0 & 19225.0 & 27223.0 & 3660.0 & 107332.0 & 169452.0 \\
\hline 3 & 225.0 & 795.0 & 15750.0 & 1873.0 & 6405.0 & 47387.0 & 72435.0 \\
\hline 4 & 801.6 & 18775.0 & 35650.3 & 35061.9 & 2440.0 & 86522.4 & 179251.1 \\
\hline 5 & 480.9 & 17664.0 & 35359.3 & 32660.4 & 1830.0 & 77338.3 & 165332.9 \\
\hline
\end{tabular}

* Using the Salinity Refractometer S / Mill Cat.No/2441. 
During the researche water temperature in a blanket $(0.5 \mathrm{~m})$ was $23.0-24.0^{\circ} \mathrm{C}$. The $\mathrm{pH}$ value was 8.0-9.5, which indicates the alkaline nature of the environment. The transparency of water was within 0.3-0.4 m. As for the hydrochemical composition of water and indicators of titrimetric researches, the concentration of the main ions of water $\left(\mathrm{K}^{+}, \mathrm{Na}^{+}, \mathrm{Mg}^{2+}, \mathrm{Ca}^{2+}, \mathrm{Cl}^{-}, \mathrm{SO}_{4}^{2-}, \mathrm{HCO}_{3}^{-}\right)$was quite high. By the received results according to the accepted classification [11] the water in all studied reservoirs was salty. The largest mineralization value was noted in lakes No. 2, No. 4 and No. 5 - 165 332.9$179251.1 \mathrm{mg} / \mathrm{dm}^{3}$. At the essential fluctuation band of total amount of salts in the water of the surveyed lakes No. 2, No. 4 and No. 5 in ionic structure everywhere prevailed chlorides (77 338.3$\left.107332.0 \mathrm{mg} / \mathrm{dm}^{3}\right)$ and sodium ions $\left(19225.0-35650.3 \mathrm{mg} / \mathrm{dm}^{3}\right)$. The water structure of these lakes belongs to a chloride class of group of sodium with the increased content of sulfates $[9,10]$. It is known that with growth of a mineralization the relative maintenance of ions of $\mathrm{HCO}_{3}$ decreases, and maintenance of ions of $\mathrm{Cl}^{-}, \mathrm{SO}_{4}{ }^{2-}, \mathrm{Ca}^{2+}, \mathrm{Mg}^{2+}, \mathrm{Na}^{+}, \mathrm{K}^{+}$increases. The water in lakes No. 2 , No. 4 and No. 5 is characterized by high degree of rigidity, relatively to the lakes No. 1 and No. 3, where the ionsalt composition of water show an average rigidity. The value of water mineralization in all lakes belongs to the category of brines.

The population of Artemia crustaceans in lakes No. 1, 2, 3, 4 and 5 of the Karabassky floods is presented by bisexual race, in other reservoirs females and cysts prevailed. The quantity of males was almost equal to the quantity of females in a ratio $1: 1$. Only in lake No. 5 the number of males was 3 times less than females. The nature of development of Artemia populations, maturing and representation of age stages in July and August, 2021 considerably differ in lakes No. 1, 2, 3, 4 and 5. In all reservoirs all age maturities except for lake No. 5, where Artemia nauplius stage were absent. It is known that in typical bisexual populations of Artemia the share of males, as a rule, always exceeds $30 \%$, averaging $42.4 \%[6,12,13]$.

The most part of the Artemia reservoirs of Kazakhstan are characterized by existence of Artemia parthenogenetica populations with the absence or extremely small presence of males. A significant number of males can indicate the tension of an ecological situation in the reservoirs and the aspiration of population to increase survival and resilience of posterity. In the reservoirs there are all age maturities of crustaceans. At the same time, the basis of Artemia populations in all lakes is formed by the youngest stages - the nauplius, creating 53-86\% of total number of Artemia. The mature individuals during this period are few $-15.2 \%$. And the ratio of mature and immature parts of the population in a coastal part of lakes No. 2 and 3 made $1: 50$. In lake No. 1 and in the center of lake No. 2 the ratio was less $-1: 6$. Among females there prevailed oviparous, with fertility from 15 to 80 eggs in the ovisacs. The distribution of quantitative indices of uneven-age stages of Artemia are presented in Table 3 .

Table 3

Distribution of quantitative indices of uneven-age stages of Artemia

\begin{tabular}{|c|c|c|c|c|c|c|c|}
\hline Laces & Females without cysts & Females with cysts & Males & Naupliya (larvae) & Juvenile & Predadult & Total \\
\hline \multicolumn{8}{|c|}{ Number, thousand copy $/ \mathrm{m}^{3}$} \\
\hline \multicolumn{8}{|c|}{ July, 2021} \\
\hline № 1 & 0.03 & 0.12 & 0.10 & 1.50 & - & 0.04 & 1.79 \\
\hline № 2 (coast) & 0.03 & - & 0.05 & 2.50 & 0.83 & 0.01 & 3.39 \\
\hline № 2 (center) & 0.83 & 0.32 & 1.21 & 8.33 & 3.33 & 1.67 & 15.69 \\
\hline № 3 & 0.01 & 0.17 & 0.16 & 5.50 & 0.02 & 0.50 & 6.36 \\
\hline \multicolumn{8}{|c|}{ June, 2021 years } \\
\hline № 4 & 1.0 & 2.0 & 2.5 & 7.40 & 12.20 & 3.00 & 28.1 \\
\hline № 5 & 2.3 & 1.0 & 1.0 & - & 2.00 & 1.60 & 7.9 \\
\hline \multicolumn{8}{|c|}{ Biomass, $\mathrm{g} / \mathrm{m}^{3}$} \\
\hline \multicolumn{8}{|c|}{ July, 2021} \\
\hline № 1 & 76.80 & 452.40 & 276.00 & 255.00 & - & 68.40 & 1130.4 \\
\hline № 2 (coast) & 76.80 & 0.00 & 138.00 & 425.00 & 458.33 & 17.10 & 1115.23 \\
\hline № 2 (center) & 2133.30 & 1206.40 & 4600.00 & 1416.67 & 1833.33 & 2850.00 & 14039.7 \\
\hline № 3 & 25.60 & 640.90 & 441.60 & 935.00 & 11.0 & 855.00 & 2909.1 \\
\hline \multicolumn{8}{|c|}{ July, 2021 years } \\
\hline № 4 & 2560.0 & 7400.00 & 6900.00 & 1258.00 & 6710.0 & 5130.00 & 29958.0 \\
\hline № 5 & 5888.0 & 3770.00 & 2760.00 & 0,00 & 1100.0 & 2736.00 & 16254.0 \\
\hline
\end{tabular}


At the end of August in lakes of Karabassky floods No. 4 and 5 the characteristics of Artemia populations were different. The ratio of the mature and immature parts of populations changed towards increase in a share of the mature crustaceans and made $1: 4$ in lake No. 4, and $1: 1.2$ in lake No. 5. The oviparous females here during this period were few and had eggs in the ovisaces in a germ state. The fertility of Artemias during researches is presented in Table 4.

Table 4

Fertility of Artemia during researches

\begin{tabular}{|c|c|c|c|}
\hline Resrvoir & Females, exempl./m & Fertility exempl./m & Cystes, exempl./m \\
\hline \multicolumn{4}{|c|}{ June, 2021 years } \\
\hline Lake № 1 & 120 & 15 & 500 \\
\hline Lake № 2 (coast) & 0 & 0 & 8330 \\
\hline Lake № 2 (center) & 320 & 80 & 830 \\
\hline Lake № 3 & 170 & 70 & 2500 \\
\hline \multicolumn{4}{|c|}{ July, 2021 years } \\
\hline Lake № 4 & 2000 & 50 & 1000 \\
\hline Lake № 5 & 1000 & 60 & 1000 \\
\hline
\end{tabular}

From Tables 3 and 4 it can be seen that the level of quantitative development of Artemia Branchiopoda crustaceans in the small lakes of Pribalkhashye (№ 1-5) in July and at the end of August is quite considerable. At the same time the populations of Artemia at the end of September in lakes No. 4 and 5 are much more numerous, than at the end of July in lakes No. 1, 2 and 3. The median number of crustaceans in September for lakes № 4 and 5 exceeds that in lakes № 1, 2 and 3 in July. Also Artemia biomass raised five times at the expense of larger, mature crustaceans prevailing as a part of population by the end of summer. It is possible to tell that in September in the explored small lakes of Pribalkashye the third Artemia generation was observed. Assessing the biomass of Artemia in the lakes No. 1, 2, 3, 4 and 5 of Karabassky floods, according to the adopted characteristics [7, 13], itcan be inferred that lake No. 4 on the biomass indicators of Artemia $-29.96 \mathrm{~g} / \mathrm{m}^{3}$ is highly productive. Lakes No. 1, 2, 3 of Karabassky floods (coastal) with biomass of Artemia 1,13, 1,12 and $2.91 \mathrm{~g} / \mathrm{m}^{3}$, respectively, are low-productive reservoirs, lake No. 5 with biomass of $16.25 \mathrm{~g} / \mathrm{m}^{3}$ are characterized of medium product.

Despite considerable quantitative development of Artemia crustaceans, the density of the lakes which are freely floating cysts in plankton, was low and changed from $500 \mathrm{pcs} / \mathrm{m}^{3}$ in lake No. 1 up to $8330 \mathrm{pcs} / \mathrm{m}^{3}$ in a coastal of lake No. 2. Their biomass at the same time fluctuated ranging from 5.0 up to $83.3 \mathrm{mg} / \mathrm{m}^{3}$ that corresponds to low indicators. In the literature it is indicated that the reserve of cyst depends on biomass of crustaceans and that cysts are more produced by the third Artemia generation [13]. The reserves of autumn plankton cysts of small, shallow-water lakes No. 4 and 5 of the Karabassky floods were calculated by the formula of the autumn plankton cysts.

To evaluate the condition of Artemia crustacean and cyst populations in the small lakes of Pribalkhashye of the Karabassky floods, the comparison of their quantitative development to similar data of stocks relatively cysts of the salt lakes of North Kazakhstan in 2016 is carried out [9]. The quantitative indicators of Artemia of the lakes of the Karabassky floods and lakes of North Kazakhstan are presented in Table 5.

Table 5

\section{Quantitative indicators of Artemia from the lakes of the Karabassky floods and lakes of North Kazakhstan}

\begin{tabular}{|c|c|c|c|c|c|c|c|c|c|}
\hline \multirow{2}{*}{$\begin{array}{c}\text { Reservoir } \\
\text { Index }\end{array}$} & \multicolumn{2}{|c|}{ Artemia population } & \multicolumn{2}{|c|}{ Artemia cysts in plankton } & \multicolumn{2}{|c|}{ Artemia population } & \multicolumn{3}{|c|}{ Artemia cysts in plankton } \\
\hline & expl./m $\mathbf{m}^{3}$ & $\mathrm{~g} / \mathrm{m}^{3}$ & $\operatorname{expl} . / \mathrm{m}^{3}$ & $\mathrm{~g} / \mathrm{m}^{3}$ & Index & $\operatorname{expl} / \mathbf{m}^{3}$ & $\mathrm{~g} / \mathrm{m}^{3}$ & $\operatorname{expl} / \mathbf{m}^{3}$ & $\mathrm{~g} / \mathrm{m}^{3}$ \\
\hline \multicolumn{5}{|c|}{ Karabassky floods (2021) } & \multicolumn{5}{|c|}{ Lakes of the North Kazakhstan region (2016) } \\
\hline Lake № 1 & 1.79 & 1.13 & 0.50 & 0.005 & Ushsai & 2.7 & 1.79 & 1792.2 & 17.922 \\
\hline Lake № 2 & 15.69 & 14.04 & 0.83 & 0.008 & Kalibek & 1.0 & 2.297 & 428.6 & 4.286 \\
\hline Lake № 3 & 6.36 & 2.91 & 2.50 & 0.025 & Mengisor & 4.0 & 0.170 & 562.1 & 5.621 \\
\hline Lake № 4 & 28.1 & 29.96 & 1.0 & 0.01 & Stanovoe & 10.0 & 11.558 & 85 & 0.850 \\
\hline Lake № 5 & 7.9 & 16.25 & 1.0 & 0.01 & Solenoe & 3.3 & 1.331 & 74.9 & 0.749 \\
\hline
\end{tabular}


The quantitative development of Artemia crustaceans in lakes of the Karabassky floods is comparable with that in lakes of the North Kazakhstan area, perspective on cyst [4, 5]. Moreover, the indicators of number and biomass of Artemia in the lakes under study exceed the similar indicators of the North Kazakhstan reservoirs. But the cysts quantity in plankton of the lakes of the Karbassky floods is 2-3 orders is lower, than in the North Kazakhstan reservoirs. However, we calculated the expected reserves of autumn cysts in plankton for lakes of the Karbassky floods by the biomass of Artemia crustaceans of the third, August, generation made as it was specified earlier, $3.69 \mathrm{~g} / \mathrm{m}^{2}$. This value is slightly smaller than the average reserves of cysts $\left(5.19 \mathrm{~g} / \mathrm{m}^{3}\right)$ in the plankton lakes of the North Kazakhstan region in 2016, which indicates the perspective of the studied small reservoirs of the Pribalkhashye with respect to autumn plankton cysts.

\section{Conclusion}

In the lakes Artemia crustaceans are presented by bisexual parthenogenetica race, with all age stages of development during the summer -autumnal period of observations. The hydrochemical mode of hypergaline lakes of the Karabassky floods is favorable for the activity of Artemia Branchiopoda crustaceans. The size of crustacean populations biomass in Lake Balhash changes on seasons ranging from low to very high. Lake No. 1 is highly productive in Artemia in the summer, and lake No. 2 - in the spring. Such difference in temporary aspect is caused by existence of various generations in the crustacean populations on seasons.

\section{REFERENCES}

1. Sharapova L. I., Shalgimbaeva G. M., Isbekov K. B., Troshina T. T., Nurieva Sh. B., Tursunbaev A. U. Biologicheskie kharakteristiki i vidovaia geneticheskaia identifikatsiia populiatsii artemii v raznotipnykh vodoemakh Kazakhstana [Biological characteristics and specific genetic identification of Artemia populations in polytypic reservoirs of Kazakhstan]. Nauka, tekhnika i obrazovanie, 2016, no. 9 (27), pp. 15-25.

2. Shalgimbaeva G. M., Volkov A. A. Izmenchivost' mikrosatellitnykh lokusov prirodnykh populiatsii rachka artemii (Artemia parthenogenetica) solianykh vodoemov Kazakhstana [Variability of microsatellite loci of natural populations of the crustacean of Artemia parthenogenetica of the salt reservoirs of Kazakhstan]. Genetika populiatsii: progress i perspektivy: materialy Mezhdunarodnoi nauchnoi konferentsii, posviashchennoi 80-letiiu akademika Iu. P. Altukhova i 45-letiiu laboratorii populiatsionnoi genetiki IOGen RAN (Zvenigorodskaia biostantsiia biologicheskogo fakul'teta MGU im. M. V. Lomonosova, 17-21 aprelia 2017 g.). Moscow, Izd-vo «Vash format», 2017. Pp. 320-321.

3. Litvinenko L. I., Litvinenko A. I., Boiko E. G. Artemiia v ozerakh Zapadnoi Sibiri [Artemia in lakes of Western Siberia]. Novosibirsk, Nauka Publ., 2009. 304 p.

4. Sharapova L. I., Troshina T. T., Fefelov V. V., Nurieva Sh. B., Tursunbaev A. U. Sovremennoe sostoianie i produktivnost' populiatsii Artemia sp. (Crustacea, Anostraca) v usloviiakh solianykh ozer Severo-Kazakhstanskoi oblasti Respubliki Kazakhstan [Current state and productivity of populations of Artemia sp. (Crustacea, Anostraca) in conditions of salt lakes of North Kazakhstan region of Republic of Kazakhstan]. Evropeiskii zhurnal tekhnicheskikh i estestvennykh nauk, 2017, no. 3, pp. 3-8.

5. Sharapova L. I. Artemia sp. v solianykh ozerakh iugo-vostoka Kazakhstana [Artemia sp. in salt lakes of southeast of Kazakhstan]. Agrarnaia nauka - sel'skokhoziaistvennomu proizvodstvu Sibiri, Kazakhstana, Mongolii, Belarusi i Bolgarii: sbornik nauchnykh dokladov XX Mezhdunarodnoi nauchno-prakticheskoi konferentsii (Novosibirsk, 4-6 oktiabria 2017 g.). Novosibirsk, Izd-vo SFNTs RAN, NGAU, 2017. Pp. 489-491.

6. Metodicheskoe posobie pri gidrobiologicheskikh rybokhoziaistvennykh issledovaniiakh vodoemov Kazakhstana (plankton, zoobentos) [Teaching aids for hydrobiological fishery researches of reservoirs of Kazakhstan (plankton, zoobenthos)]. Almaty, 2006. 27 p.

7. Metodicheskie ukazaniia po opredeleniiu obshchikh dopustimykh ulovov (ODU) tsist zhabronogogo rachka Artemia [Methodical instructions by definition of general admissible catches (GAC) of cyst of crustacean Artemia]. Tiumen', SibrybNII proekt, 2002. 26 p.

8. Voronov P. M. Solevoi sostav vody i izmenchivost' Artemia salina (L.) [Salt composition of water and variability of Artemia salina (L.)]. Zoologicheskii zhurnal, 1979, vol. 58, iss. 2, pp. 175-178.

9. ST RK GOST R 51592-2003. Voda. Obshchie trebovaniia $k$ otboru prob [ST RK GOST P 515922003. Water. General requirements to sampling]. Astana, 2003. 59 p.

10. GOST 26449.1-85. Ustanovki distilliatsionnye opresnitel'nye statsionarnye. Metody khimicheskogo analiza solenykh vod [GOST 26449.1-85. Distillation desalination stationary units. Methods of chemical analysis of salty waters]. Moscow, Izd-vo standartov, $1985.45 \mathrm{p}$.

11. Alekin O. A. Osnovy gidrokhimii [Principles of hydrochemistry.]. Leningrad, Gidrometeorol. izd-vo, 1970. 444 p. 
12. Solovov V. P., Podurovskii M. A., Iasiuchenia T. L. Zhabronog artemiia i perspektivy ispol'zovaniia resursov [Artemia Branchiopoda and prospects for using resources]. Barnaul, Altais. poligraf. kombinat, 2001. $144 \mathrm{p}$.

13. Litvinenko A. I. Zhabronogie rachki roda Artemia leach, 1819 v gipergalinnykh vodoemakh zapadnoi Sibiri (geografiia, bioraznoobrazie, ekologiia, biologiia i prakticheskoe ispol'zovanie). Avtoreferat dissertatsii ... d-ra biol. nauk [Branchiopoda crustaceans of the sort Artemia leach, 1819 in hypergaline ponds of Western Siberia (geography, biodiversity, ecology, biology and practical use. Diss.Abstr. ...Dr.Bio.Sci.]. Perm', 2009. 29 p.

The article submitted to the editors 14.07.2021

\title{
INFORMATION ABOUT THE AUTHORS
}

Zhanara O. Mazhibayeva - PhD (Doctor of Philosophy); Head of the Laboratory of Hydrobiology and Hydroanalytics; Fisheries Research and Production Center, LLP; Republic of Kazakhstan, 050010, Almaty; mazhibaeva@bk. ru.

Tynysbek T. Barakbayev - PhD (Doctor of Philosophy); Head of the Aral branch; Fisheries Research and Production Center, LLP; Republic of Kazakhstan, 050010, Almaty; barakbayev@fishrpc.kz.

Gulmira M. Shalgimbayeva - Head of the Laboratory of Genetics of Hydrobionts; Fisheries Research and Production Center, LLP; Republic of Kazakhstan, 050010, Almaty; shalgimbayeva@mail.ru.

Kuanysh B. Isbekov - Candidate of Biology, Assistant Professor; General Director; Fisheries Research and Production Center, LLP; Republic of Kazakhstan, 050016, Almaty; isbekov@mail.ru.

Saule Zh. Assylbekova - Doctor of Biological Sciences, Assistant Professor; Deputy General Director; Fisheries Research and Production Center, LLP; Republic of Kazakhstan, 050016, Almaty; assylbekova@mail.ru.

Viktor V. Fefelov - Head of the Reference Point; Fisheries Research and Production Center, LLP; Republic of Kazakhstan, 050010, Almaty; Fefelov@fishrpc.kz.

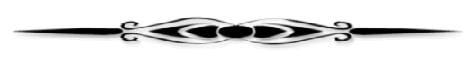

\section{ПОПУЛЯЦИИ РАЧКА АРТЕМИЯ КАРАБАССКИХ РАЗЛИВОВ ПРИБАЛХАШЬЯ}

\author{
Ж. О. Мажибаева, Т. Т. Баракбаев, Г. М. Шалгимбаева, \\ К. Б. Исбеков, С. Ж. Асылбекова, В. В. Фефелов
}

ТОО «Научно-производственный иентр рыбного хозяйства»,
Алматы, Республика Казахстан

Представлен анализ биологических показателей партеногенеза артемии - представителя ракообразных гипергалинных водоемов Казахстана. Показаны изменения общей биомассы ракообразных в нескольких исследованных озерах в сторону снижения - от высокопродуктивного к низкопродуктивному. Большая часть водоемов Казахстана с артемией характеризуется наличием популяций Artemia parthenogenetica с отсутствием или крайне небольшим присутствием самцов. Появление самцов в значительных количествах может свидетельствовать о напряженности экологической ситуации в водоемах и стремлении популяции повысить выживаемость и устойчивость потомства. Отмечается, что водоемах присутствуют ракообразные на всех возрастных сроках созревания. В то же время основу популяций артемии во всех исследованных озерах составляют самые молодые стадии - науплиусы, образующие 
53-86 \% от общего числа артемий. В озерах рачок артемия представлен бисексуальной партеногенетической расой, со всеми возрастными стадиями развития в летне-осенний период наблюдений. Гидрохимический режим гипергалинных озер Карабасских разливов благоприятен для жизнедеятельности жаброногого рачка артемии. Величина биомассы рачков прибалхашских популяций менялась по сезонам в пределах от низкой до очень высокой. Озеро № 1 высокопродуктивно артемией летом, а озеро № 2 - весной. Такая разница во временном аспекте обусловлена наличием различных генераций в популяциях рачка по сезонам. Полученные данные позволяют говорить о перспективности изученных малых водоемов Прибалхашья в отношении осенних цист планктона.

Ключевые слова: озера, популяция, артемия, ракообразные, цисты, биомасса, планктон.

Для цитирования: Мажибаева Ж. О., Баракбаев Т. Т., Шалгимбаева Г. М., Исбеков К. Б., Асылбекова С. Ж., Фефелов В. В. Популяции рачка артемия Карабасских разливов Прибалхашья // Вестник Астраханского государственного технического университета. Серия: Рыбное хозяйство. 2021. № 3. С. 47-54. DOI: 10.24143/2073-5529-2021-3-47-54.

\section{СПИСОК ЛИТЕРАТУРЫ}

1. Шарапова Л. И., Шалгимбаева Г. М., Исбеков К. Б., Трошина Т. Т., Нуриева Ш. Б., Турсунбаев А. У. Биологические характеристики и видовая генетическая идентификация популяций артемии в разнотипных водоемах Казахстана // Наука, техника и образование. 2016. № 9 (27). С. 15-25.

2. Шалгимбаева Г. М., Волков А. А. Изменчивость микросателлитных локусов природных популяций рачка артемии (Artemia parthenogenetica) соляных водоемов Казахстана // Генетика популяций: прогресс и перспективы: материалы Междунар. науч. конф., посвящ. 80-летию акад. Ю. П. Алтухова и 45-летию лаборатории популяц. генетики ИОГен РАН (Звенигородская биостанция биолог. фак. МГУ им. М. В. Ломоносова, 17-21 апреля 2017 г.). М.: Изд-во «Ваш формат», 2017. С. 320-321.

3. Литвиненко Л. И., Литвиненко А. И., Бойко Е. Г. Артемия в озерах Западной Сибири. Новосибирск: Наука, 2009. 304 с.

4. Шарапова Л. И., Трошина Т. Т., Фефелов В. В., Нуриева Ш. Б., Турсунбаев А. У. Современное состояние и продуктивность популяций Artemia sp. (Crustacea, Anostraca) в условиях соляных озер Северо-Казахстанской области Республики Казахстан // Европейский журнал технических и естественных наук. 2017. № 3. С. 3-8.

5. Шарапова Л. И. Artemia sp. в соляных озерах юго-востока Казахстана // Аграрная наука - сельскохозяйственному производству Сибири, Казахстана, Монголии, Беларуси и Болгарии: сб. науч. докл. ХХ Междунар. науч.-практ. конф. (Новосибирск, 4-6 октября 2017 г.). Новосибирск: Изд-во СФНЦ РАН, НГАУ, 2017. С. $489-491$.

6. Методическое пособие при гидробиологических рыбохозяйственных исследованиях водоемов Казахстана (планктон, зообентос). Алматы, 2006. 27 с.

7. Методчческие указания по определению общих допустимых уловов (ОДУ) цист жаброногого рачка Artemia. Тюмень: СибрыбНИИ проект, 2002. 26 с.

8. Воронов П. М. Солевой состав воды и изменчивость Artemia salina (L.) // Зоол. журн. 1979. T. 58. Вып. 2. С. 175-178.

9. СТ РК ГОСТ Р 51592-2003. Вода. Общие требования к отбору проб. Астана, 2003. 59 с.

10. ГОСТ 26449.1-85. Установки дистилляционные опреснительные стационарные. Методы химического анализа соленых вод. М.: Изд-во стандартов, 1985. 45 с.

11. Алекин О. А. Основы гидрохимии. Л.: Гидрометеорол. изд-во, 1970. 444 с.

12. Соловов В. П., Подуровский М. А., Ясюченя Т. Л. Жаброног артемия и перспективы использования ресурсов. Барнаул: Алтайс. полиграф. комбинат, 2001. 144 с.

13. Литвиненко А. И. Жаброногие рачки рода Artemia leach, 1819 в гипергалинных водоемах западной Сибири (география, биоразнообразие, экология, биология и практическое использование): автореф. дис. ... д-ра биол. наук. Пермь, 2009. 29 с.

Статья поступила в редакцию 14.07.2021

\section{ИНФОРМАЦИЯ ОБ АВТОРАХ}

Жанара Омирбековна Мажибаева - PhD (доктор философии); зав. лабораторией гидробиологии и гидроаналитики; ТОО «Научно-производственный центр рыбного хозяйства»; Республика Казахстан, 050016, Алматы; mazhibaeva@bk.ru. 
Тынысбек Темирханович Баракбаев - PhD (доктор философии); директор Аральского филиала; ТОО «Научно-производственный центр рыбного хозяйства»; Республика Казахстан, 050016, Алматы; barakbayev@fishrpc.kz.

Гульмира Мухметкалиевна Шалгимбаева - зав. лабораторией генетики гидробионтов; ТОО «Научно-производственный центр рыбного хозяйства»; Республика Казахстан, 050016, Алматы; shalgimbayeva@mail.ru.

Куаныш Байболатович Исбеков - канд. биол. наук, доцент; генеральный директор; ТОО «Научно-производственный центр рыбного хозяйства»; Республика Казахстан, 050016, Алматы; isbekov@mail.ru.

Сауле Жангировна Асылбекова - д-р биол. наук, доцент; зам. генерального директора; ТОО «Научно-производственный центр рыбного хозяйства»; Республика Казахстан, 050016, Алматы; assylbekova@mail.ru.

Виктор Владимирович Фефелов - зав. опорным пунктом; ТОО «Научно-производственный центр рыбного хозяйства»; Республика Казахстан, 050016, Алматы; Fefelov@fishrpc.kz. 